\title{
Response of annual canarygrass (Phalaris canariensis L.) to nitrogen fertilizer and fungicide applications
}

\author{
William E. May, Joseph C. Train, and Lindsey Greidanus
}

\begin{abstract}
Annual canarygrass (Phalaris canariensis L.) is a specialty crop grown in Canada and the harvested grain is primarily used to feed wild and domesticated bird species. A field experiment was conducted at 5 locations in both 2012 and 2013 to study the response of annual canarygrass development and grain yield to the combined effects of fungicide (propiconazole + trifloxystrobin) and nitrogen $(\mathrm{N})$ fertilizer, and to determine the minimum number of site years required to detect these effects. The experimental design was a split plot with fungicide application (none or fungicide) as the main plot and $\mathrm{N}$ application rate as the sub plot $\left(10,20,30,50,70,90 \mathrm{~kg} \mathrm{~N} \cdot \mathrm{ha}^{-1}\right)$. There was a linear increase of $14.5 \%$ in grain yield as the rate of $\mathrm{N}$ fertilizer increased. The fungicide application increased the grain yield $8.5 \%$ by increasing kernel density from 15197 kernels m${ }^{-2}$ to 16288 kernels m$^{-2}$. There was no interaction between the $\mathrm{N}$ rate and fungicide application. The application of a fungicide did not increase the responsiveness of annual canarygrass to $\mathrm{N}$ fertilizer. The lack of an interaction between $\mathrm{N}$ and fungicide application indicates that these two practices can be managed independently by annual canarygrass producers. To optimize grain yield producers should apply $50 \mathrm{~kg} \mathrm{~N} \cdot \mathrm{ha}^{-1}$ and apply a fungicide to increase grain yield especially in regions where septoria leaf mottle is prevalent. The number of site years needed to consistently detect the impact of $\mathrm{N}$ and fungicide on the grain yield were 4 and 5 site years, respectively.
\end{abstract}

Key words: annual canarygrass, septoria leaf mottle, fungicide application, nitrogen fertilizer, grain yield.

Résumé : Le phalaris des Canaries (Phalaris canariensis L.) est une culture de spécialité canadienne. Ses graines servent essentiellement de nourriture aux oiseaux sauvages ou domestiqués. En 2012 et 2013, les auteurs ont procédé à une expérience sur le terrain, à cinq endroits, en vue d'établir comment la croissance du phalaris et son rendement grainier réagissent aux effets combinés d'un fongicide (propiconazole + trifloxystrobine) et d'un engrais azoté (N), ainsi que pour déterminer le nombre minimal d'années-sites requis pour déceler ces effets éventuels. L'expérience suivait un dispositif en tiroir, la parcelle principale ayant reçu ou pas du fongicide, et la parcelle secondaire, de l'engrais $\mathrm{N}$ à raison de 10, 20,30,50, 70 ou $90 \mathrm{~kg}$ par hectare. Le rendement grainier augmente linéairement de 14,5\% avec le taux d'application de l'engrais. L'usage d'un fongicide accroît le rendement grainier de 8,5 \%, grâce à une plus grande densité des graines, qui passe de 15197 à 16288 par m$^{2}$. Les auteurs n'ont relevé aucune interaction entre le taux d'application du $\mathrm{N}$ et l'usage d'un fongicide. Le fongicide n'améliore pas la réaction de la graminée annuelle à l'engrais azoté. L'absence d'interaction entre le taux d'application de l'engrais et le fongicide indique que les producteurs de phalaris des Canaries peuvent gérer ces deux pratiques indépendamment. Pour optimiser le rendement grainier, le producteur devrait appliquer $50 \mathrm{~kg}$ de $\mathrm{N}$ par hectare puis un fongicide, surtout dans les régions où sévit la tache septorienne. Il faut compter respectivement quatre ou cinq années-sites pour déceler l'impact de l'engrais $\mathrm{N}$ et du fongicide sur le rendement grainier de la culture. [Traduit par la Rédaction]

Mots-clés : phalaris des canaries, tache septorienne, application de fongicide, engrais azoté, rendement grainier.

\section{Introduction}

Annual canarygrass (Phalaris canariensis L.), also called canary seed, is a cereal crop grown in the prairie region of Canada, which is the largest producer and exporter of annual canarygrass worldwide (Tridge 2020). In 2018, 100000 hectares were harvested in Canada, producing around 146000 tonnes of grain worth $\$ 73730000$ (CAD) (Agriculture and Agri-Food Canada 2020; Tridge 2020).

Received 30 July 2020. Accepted 6 April 2021.

W.E. May, J.C. Train, and L. Greidanus. Agriculture and Agri-Food Canada (AAFC), Indian Head Research Farm, RR\#1 Government Rd., P.O. Box 760, Indian Head, SK SOG 2K0, Canada.

Corresponding author: William E. May (email: william.may@agr.gc.ca).

(C) 2021. Her Majesty the Queen in Right of Canada, as represented by the Minister of Agriculture and Agri-Food Canada. This work is licensed under a Creative Commons Attribution 4.0 International License (CC BY 4.0), which permits unrestricted use, distribution, and reproduction in any medium, provided the original author(s) and source are credited. 
Currently, the major use of annual canarygrass is as a feed for both caged and wild bird species. The grain of annual canarygrass has higher concentrations of the eight essential amino acids than wheat (Triticum aestivum L.) or corn (Zea mays L.) and a higher level of protein then most comparable grains (Putnam et al. 1996). Due to its unique nutrient profile, it is starting to enter the food market for human consumption, as a glutenfree cereal. In 2016, Health Canada (2016) approved glabrous (hairless) annual canarygrass, a gluten-free grain for human consumption. Currently, small amounts are used in health food drinks produced and sold in Latin America.

Annual canarygrass originates from the Mediterranean region and is a grain crop that is most closely related to oat (Avena sativa L.) (Putnam et al. 1996). While it is currently grown in Europe, Asia, Australia, and the Americas, the biggest producer is Canada, specifically Saskatchewan (Tridge 2020). It is an annual crop that can reach between $50 \mathrm{~cm}$ and $100 \mathrm{~cm}$ tall with a compressed oval shaped panicle. This crop prefers clay soils with good moisture retention due to its shallow rooting depth (Putnam et al. 1996). Annual canarygrass is usually planted in May and takes 95-110 d to mature (May et al. 2012a).

Annual canarygrass growth, development, and grain yield can benefit from the application of nutrients, especially $\mathrm{N}$ and chloride $\left(\mathrm{Cl}^{-}\right)$(May et al. 2012a, 2012b). The positive impact of $\mathrm{N}$ fertilizer on annual canarygrass grain yield has been observed in several studies. A field trial at Indian Head from 1978-1983 found a curvilinear increase in grain yield as the rate of fertilizer $\mathrm{N}$ increased, with no effect on kernel weight or maturity (Holt 1988). The suggested rate of application fell between $50-75 \mathrm{~kg} \mathrm{~N} \cdot \mathrm{ha}^{-1}$ (Holt 1988). May et al. (2012a) reported that an increase in $\mathrm{N}$ fertilizer up to $78 \mathrm{~kg} \cdot \mathrm{ha}^{-1}$ resulted in an increase in grain yield. Both studies found that grain yield increased as $\mathrm{N}$ rate increased, but overall yield and the yield increase was lower (710 to $2200 \mathrm{~kg} \cdot \mathrm{ha}^{-1}$ ) compared with other cereal crops. May et al. (2004) reported that oat yields can increase to $4100 \mathrm{~kg} \cdot \mathrm{ha}^{-1}$ with $80 \mathrm{~kg} \mathrm{~N} \cdot \mathrm{ha}^{-1}$, a similar maximum $\mathrm{N}$ rate compared with annual canarygrass, but with a much higher grain yield. O'Donovan et al. (2015), found that barley (Hordeum vulgare L.) had a higher grain yield $\left(4600 \mathrm{~kg} \cdot \mathrm{ha}^{-1}\right)$ than annual canarygrass but required a higher $\mathrm{N}$ rate $\left(110 \mathrm{~kg} \mathrm{~N} \cdot \mathrm{ha}^{-1}\right)$ to maximize grain yield and Biswas and Ma (2016) reported that with $180 \mathrm{~kg}$ $\mathrm{N} \cdot \mathrm{ha}^{-1}$, corn yields can reach up to $14190 \mathrm{~kg} \cdot \mathrm{ha}^{-1}$. When evaluating an appropriate $\mathrm{N}$ rate to recommend for annual canarygrass production it is important to consider the sensitivity of the $\mathrm{N}$ rate recommendation to changes in the price of crop and $\mathrm{N}$ fertilizer. This becomes even more important if in the future $\mathrm{N}$ fertilizer prices are elevated to reduce excess $\mathrm{N}$ fertilization and green house gas production (Meyer-Aurich et al. 2020).
As the supply of $\mathrm{N}$ to the crop is increased there are physiological structural changes that can occur in a cereal plant to increase its susceptibility to lodging including basal internodes with smaller diameters, fewer support roots per stem, and a lower root dry weight per stem and as lodging increases grain yield often decreases (Berry et al. 2004; Easson et al. 1993). May et al. (2012a) found that increased lodging as the $\mathrm{N}$ rate increased occurred in a few site years, but not consistently across years and locations. Also, a microclimate can be created by lodging that fosters disease development that further reduces leaf area as well as grain yield (Nakajima et al. 2008).

Annual canarygrass faces a number of biotic stresses during the growing season including weeds, aphids, and disease. These pests can lower yield and increase the production costs incurred to control these pests, thereby lowering the profitability of annual canarygrass. For annual canarygrass, the most relevant disease is septoria leaf mottle caused by Septoria triseti Speg. (Kaminski 1994). The fungus produces pale tan to gray lesions that appear on the leaf blades and sheaths (Berkenkamp 1989). First observed on annual canarygrass in 1988, septoria leaf mottle restricts photosynthetic capacity, which causes the plants to produce smaller kernels, lowering grain yield, and causing an economic loss to growers (Kaminski 1994). Field scale trials conducted between 2008 and 2013 at Indian Head found that annual canarygrass had a large and consistent grain yield response in every year to a fungicide application to control septoria leaf mottle (Holzapfel 2014). Holzapfel (2014) found that the increase in grain yield from a fungicide ranged from $4 \%$ to $67 \%$, and the average response over the 6 years was 23\%. In addition, he found that annual canarygrass was more responsive to a fungicide application than the other cereals tested including, oat, wheat and barley.

Previous research has demonstrated that annual canarygrass responds to both the application of a fungicide and the application rate of $\mathrm{N}$ fertilizer; however, the combined effect of a fungicide application and $\mathrm{N}$ fertilizer has not been studied (Holzapfel 2014; May et al. 2012a). The objectives of this study were to determine if a fungicide application and nitrogen management have any synergistic effects on the growth, development, grain yield and gross return of annual canarygrass and to determine the minimum number of site years required to detect these effects using the data from this study.

\section{Materials and Methods}

This study was conducted in 2012 and 2013 across 5 locations in Saskatchewan: Melfort $\left(52^{\circ} 49^{\prime} 6.29^{\prime \prime} \mathrm{N}\right.$, $104^{\circ} 36^{\prime} 11.77^{\prime \prime} \mathrm{W}$ and elevation $478 \mathrm{~m}$ ), Indian Head $\left(50^{\circ} 31^{\prime} 58.48^{\prime \prime} \mathrm{N}, 103^{\circ} 39^{\prime} 2.91^{\prime \prime} \mathrm{W}\right.$ and elevation $\left.582 \mathrm{~m}\right)$, Swift Current $\left(50^{\circ} 16^{\prime} 49.56^{\prime \prime} \mathrm{N}, 107^{\circ} 47^{\prime} 58.39^{\prime \prime} \mathrm{W}\right.$ and elevation $748 \mathrm{~m}$ ), Redvers $\left(49^{\circ} 34^{\prime} 21.82^{\prime \prime} \mathrm{N}, 101^{\circ} 41^{\prime} 53.54^{\prime \prime} \mathrm{W}\right.$ and 
Table 1. Agronomic information for each of the individual site years.

\begin{tabular}{lllllll}
\hline Location & Year & $\begin{array}{l}\text { Row } \\
\text { spacing } \\
(\mathrm{cm})\end{array}$ & $\begin{array}{l}\text { Spring } \\
\text { residual } \\
\mathrm{N}\left(\mathrm{kg} \cdot \mathrm{ha}^{-1}\right)\end{array}$ & $\begin{array}{l}\text { Seeding } \\
\text { date }\end{array}$ & $\begin{array}{l}\text { Harvest } \\
\text { area }(\mathrm{m} \times \mathrm{m})\end{array}$ & $\begin{array}{l}\text { Harvest } \\
\text { date }\end{array}$ \\
\hline Melfort & 2012 & 20.3 & 47.0 & 15 May & $1.4 \times 5.5$ & 5 Oct. \\
& 2013 & 20.3 & 31.0 & 16 May & $1.3 \times 10$ & 18 Sept. \\
Indian Head & 2012 & 30.5 & 10.1 & 15 May & $2.1 \times 10.7$ & 4 Oct. \\
& 2013 & 30.5 & 21.0 & 13 May & $2.1 \times 10.7$ & 8 Oct. \\
Scott & 2012 & 25.4 & 23.6 & 21 May & $4 \times 10$ & 1 Oct. \\
Swift Current & 2013 & 25.4 & 29.2 & 23 May & $1.5 \times 10$ & 17 Sept. \\
& 2012 & 22.9 & 35.3 & 2 June & $1.4 \times 5.5$ & 16 Oct. \\
Redvers & 2013 & 22.9 & 35.7 & 21 May & $1.4 \times 5.5$ & 15 Sept. \\
& 2012 & 25.4 & 41.1 & 16 May & $1.2 \times 9.1$ & 7 Oct. \\
& 2013 & 25.4 & 51.6 & 22 May & $1.2 \times 9.1$ & 30 Sept.
\end{tabular}

elevation $594 \mathrm{~m})$ and Scott $\left(52^{\circ} 21^{\prime} 40.73^{\prime \prime} \mathrm{N}\right.$, $108^{\circ} 50^{\prime} 15.85^{\prime \prime} \mathrm{W}$ and elevation $655 \mathrm{~m}$ ). The experimental design was a split plot with fungicide application (none or Stratego ${ }^{\circledR}$, propicoazole $62 \mathrm{~g}$ a.i. ha ${ }^{-1}$ and trifloxystrobin $62 \mathrm{~g}$ a.i. $\mathrm{ha}^{-1}$ ) as the main plot and $\mathrm{N}$ application rate as the sub plot $\left(10,20,30,50,70,90 \mathrm{~kg} \mathrm{~N} \cdot \mathrm{ha}^{-1}\right)$. A gap of at least one sub plot was placed between the unsprayed and sprayed main plots to ensure that spray drift did not reach the unsprayed main plots during fungicide application and that disease develop in the unsprayed main plots did not quickly spread back into the sprayed main plots. The applied $\mathrm{N}$ rates were not adjusted for the residual $\mathrm{N}$ level in the soil. There were four replicates at each location. Each site used their own research seeder to seed the experiment. Plot size ranged from $1.4 \mathrm{~m} \times 5.5 \mathrm{~m}$ in Swift Current and Melfort to $4 \mathrm{~m} \times 10 \mathrm{~m}$ in Scott. (Table 1). The experiments were seeded between 15 May and 2 June. CDC Bastia was the annual canarygrass cultivar used and was seeded at a rate of $35 \mathrm{~kg} \cdot \mathrm{ha}^{-1}$. All seed lots of annual canarygrass used in this study had a germination percentage above $85 \%$. The source of $\mathrm{N}$ was urea with a $\mathrm{N}$ concentration of $46 \%$. At each site, phosphorus (P), potassium (K), Cl and sulphur (S) were side banded during seeding to each plot to provide $20 \mathrm{~kg} \mathrm{P}_{2} \mathrm{O}_{5} \cdot \mathrm{ha}^{-1}, 10 \mathrm{~kg} \mathrm{~K} \mathrm{O} \cdot \mathrm{ha}^{-1}$, $6.5 \mathrm{~kg} \mathrm{Cl} \cdot \mathrm{ha}^{-1}$ and $10 \mathrm{~kg} \mathrm{~S} \cdot \mathrm{ha}^{-1}$. Plot drills using hoe type openers were used in a no-till cropping system. All fertilizer was side banded at seeding, placed $3 \mathrm{~cm}$ to $4 \mathrm{~cm}$ to the side and $7 \mathrm{~cm}$ below the seed. Glyphosate was applied before seeding at Indian Head at $360 \mathrm{~g}$ a.e. ha $^{-1}$. In crop broadleaf herbicides were determined for each seeding date and site according to weed species density. The fungicide application occurred after the flag leaf was fully emerged with a plot sprayer.

\section{Data collection}

Soil was collected before seeding at depths of 0-15 cm and $15-60 \mathrm{~cm}$ for determining the availability of nutrients $\mathrm{N}, \mathrm{P}$, and $\mathrm{K}$. A sodium bicarbonate $\left(\mathrm{NaHCO}_{3}\right)$ extraction procedure (Hamm et al. 1970) was used to estimate residual soil $\mathrm{N}$ (nitrate; $\mathrm{NO}_{3}$ ), $\mathrm{P}$, and $\mathrm{K}$. Plant density was measured approximately three weeks after seeding. The number of plants were counted at two separate locations in the plot and at each location plants were counted in $1 \mathrm{~m}$ of one row. Panicle density, plant height, and lodging were each measured during grain filling (Zadocks 73 to 83). For each plot, the number of panicles was measure at two separate locations in the plot and at each location panicles were counted in $1 \mathrm{~m}$ of one row. Plant height was measured at two locations in each plot prior to harvest. Lodging of plants was a visual rating on the entire plot prior to harvest on a scale of 1-10, where 1 represented full standing plants and 10 represented plants completely flat on the ground. Leaf disease severity caused by septoria leaf mottle was assessed using the McFadden scale (0 to 11 ), a quantitative ordinal scale, on the entire plant canopy before plant maturity was reached (Zadocks 80 to 83) (McFadden 1991). Grain yield was determined with a self-propelled plot combine harvesting a between 7.7 to $22.5 \mathrm{~m}^{2}$ of each plot depending on the site and year (Table 1). The harvest occurred between 15 Sept. and 16 Oct. (Table 1). Grain yield was corrected to a kernel moisture level of 13\% (Canaryseed Development Commission of Saskatchewan 2021). Kernel weight was calculated by approximately taking a $40 \mathrm{~mL}$ volume of seed using a small measuring cylinder and placing it in an automated seed counter, which resulted in counting between 700 and 1000 kernels and expressed as grams per 1000 kernels. Kernel density was calculated by dividing the grain yield per square metre by the kernel weight of a single seed. Test weight was measured as specified by the Canadian Grain Commissions Official Grain Grading Guide (2016) using a cox funnel to fill a $0.5 \mathrm{~L}$ cylindrical cup and then weighting the cup (g $0.5 \mathrm{~L}^{-1}$ ) after a hardwood striker is used to scalp off the excess grain from the top of the cup.

\section{Change in gross return}

The gross return for each combination of $\mathrm{N}$ fertilizer cost and seed value was calculated by using the following equation: 
Gross return $=($ grain yield $\times$ grain price $)$ $-(\mathrm{N}$ rate $\times$ fertilizer price $)$

Three N prices were chosen: $0.50,0.65$ and $1.00 \$ \cdot \mathrm{kg}^{-1}$. The 0.50 and 0.75 represents the current range in the cost of $\mathrm{N}$ fertilizer while the $\$ 1.00 \mathrm{~kg}^{-1}$ price represents an elevated price that might be established by government policy to reduce $\mathrm{N}$ fertilizer use to combat global warming (Meyer-Aurich et al. 2020). Three grain prices were chosen: $0.44,0.66$ and $0.88 \$ \cdot \mathrm{kg}^{-1}$. These prices cover the usual price range of the annual canarygrass crop price from low to high (Government of Saskatchewan 2020a). Together, the three $\mathrm{N}$ fertilizer costs and three crop prices created nine combinations. The change in gross return was calculated by taking the gross return of each $\mathrm{N}$ rate and subtracting the gross return at the lowest $\mathrm{N}$ rate of $10 \mathrm{~kg} \cdot \mathrm{ha}^{-1}$. This provided a measure of how gross return changed over the range of $\mathrm{N}$ rates used in this study.

\section{Statistical analysis}

Mixed model analysis of data was conducted using the PROC MIXED model procedure in SAS software (Littell et al. 2006). Nitrogen application rate and fungicide application were assigned as fixed rates while the effect of the replicate and site year was considered random. Linear and quadratic contrasts were used to determine the effect of $\mathrm{N}$ on the measured variable. Unequal spacing between $N$ treatments were use, 10, $2030,50,70$, $90 \mathrm{~kg} \mathrm{~N} \cdot \mathrm{ha}^{-1}$, to ensure that changes at low $\mathrm{N}$ rates, 10 to $30 \mathrm{~N} \cdot \mathrm{ha}^{-1}$ were captured and then the interval was widened to increase the probability of exceeding the $\mathrm{N}$ required to maximize grain yield. The contrast coefficients were calculated in SAS using PROC IML (SAS Institute 2013). Statistical significance was declared at $P<0.05$ for all analysis. The random effects were only examined when they had a significant effect and account for more than $10 \%$ of the total variation associated with the random effects.

A second analysis was conducted to assess the statistical power from this existing data set when a different number of site years and replicates were used for the analysis. More specifically, the number of site years examined was 4 to 9 (maximum number of site years from the existing dataset) (Stroup 1999; W.W. Stroup personal communication). Four to 10 replicates were considered in the analysis. An iterative process was set up to run a set of SAS code for a progressively greater number of site years. The first step included PROC SURVEYSLECT (SAS Institute 2013) to randomly select the site years from the existing data set. A simple random sampling method was used. The portion of the existing dataset associated with these sites was filtered according to the site years selected. The filtered dataset was analyzed using the PROC MIXED procedure of SAS (Littell et al. 2006; SAS Institute 2013) where site year, fungicide, $\mathrm{N}$ fertilizer rate were designated as fixed effects, and replicate was considered as a random effect. The covariance parameters from this analysis were saved into a dataset for future use. The filtered dataset was then used as a base dataset which included four to 10 replicates (Stroup 1999; W.W. Stroup, personal communication). A series of SAS data steps were then used to create these 7 separate datasets with varied replication. This dataset with varied replication was analyzed using the PROC MIXED procedure of SAS (Littell et al. 2006; SAS Institute 2013) where site year, fungicide, $\mathrm{N}$ fertilizer rate were designated as fixed effects, and replicate was considered as a random effect. This analysis was repeated for each level of replication and was seeded with the covariance parameters saved from the first PROC MIXED analysis. The parms statement, pdata option was used to seed these covariance parameters. The final step with each site year iteration was to calculate power (Littell et al. 2006). After the power calculation, the process began again with an analysis with one more site year. The iterations continued until the analysis for the final number of site years (nine) was completed.

\section{Results and Discussion}

\section{Temperature and precipitation}

Monthly temperature averages and total monthly precipitation during the growing season are shown in Table 2 (Environment and Climate Change Canada 2020). September was included in the growing season due to the ability of annual canarygrass to keep growing, tillering and increasing grain yield if there is sufficient precipitation and soil moisture. In 2012, early season precipitation, Apr. and May, was above the 30-year average at all 5 locations. At three locations, Indian Head, Melfort and Scott precipitation for the rest of the growing season (Apr. to Sept.) stayed above the 30-year average while at Swift Current and Redvers, precipitation during the rest of the growing season was low enough to result in the total precipitation for the growing season being below the 30-year average. In 2013, precipitation was lower than normal for most locations over both the early and entire growing season, with Redvers having the lowest precipitation at only $67 \%$ of normal. Swift Current was the exception with $142 \%$ of the 30 -year average for growing season precipitation. All test sites had higher than normal temperature in 2012, ranging from $102 \%$ of the 30-year normal in Indian Head and Melfort, to $111 \%$ of the normal at Swift Current. Temperature was below normal for all test sites in 2013, ranging from $90 \%$ of the 30-year normal at Indian Head to $99 \%$ at Swift Current.

\section{Plant and panicle density}

Plant density was not affected by $\mathrm{N}$, fungicide application or the $\mathrm{N} \times$ fungicide application interaction (Table 3). This indicated that increasing the $\mathrm{N}$ rate had no impact on germination or emergence of the annual canarygrass. Plant density ranged from 203 to 211 plants 
Table 2. Summary of climatic conditions at sites located near Indian Head, Melfort, Scott, Swift Current, and Redvers, Saskatchewan in 2012 and 2013.

\begin{tabular}{|c|c|c|c|c|c|c|c|c|c|c|c|c|c|c|}
\hline \multirow{2}{*}{$\begin{array}{l}\text { Location/ } \\
\text { Year }\end{array}$} & \multicolumn{6}{|c|}{ Temperature $\left({ }^{\circ} \mathrm{C}\right)$} & \multirow{2}{*}{$\begin{array}{l}\text { \% of } 30 \text {-year } \\
\text { average }\end{array}$} & \multicolumn{6}{|c|}{ Precipitation (mm) } & \multirow{2}{*}{$\begin{array}{l}\% \text { of } 30 \text {-year } \\
\text { average }\end{array}$} \\
\hline & Apr. & May & June & July & Aug. & Sept. & & Apr. & May & June & July & Aug. & Sept. & \\
\hline \multicolumn{15}{|c|}{ Indian Head } \\
\hline 2012 & 4.1 & 9.9 & 16.5 & 19.2 & 17.1 & 12.6 & 102 & 50.8 & 90.6 & 51.9 & 125.7 & 30.7 & 0.2 & 116 \\
\hline 2013 & -4.6 & 11.9 & 15.3 & 16.3 & 17.1 & 14.3 & 90 & 7.6 & 18.0 & 105 & 50.9 & 7.1 & 30.3 & 73 \\
\hline 2013 & -3.9 & 12.0 & 15.4 & 16.4 & 17.7 & 14.4 & 97 & 5.8 & 19.0 & 97.9 & 103.2 & 11.7 & 18.1 & 88 \\
\hline \multicolumn{15}{|l|}{ Scott } \\
\hline 2012 & 3.8 & 9.7 & 15.1 & 18.6 & 17.0 & 12.2 & 103 & 38.4 & 50.6 & 164.6 & 56.4 & 51.6 & 25.0 & 141 \\
\hline 2013 & -2.6 & 12.7 & 14.8 & 16.5 & 17.4 & 14.0 & 99 & 11.0 & 39.3 & 115.5 & 27.3 & 64.5 & 0.4 & 94 \\
\hline \multicolumn{15}{|c|}{ Swift Current } \\
\hline 2012 & 6.3 & 11.2 & 17.3 & 21.9 & 18.8 & 13.6 & 111 & 40.2 & 88.6 & 62.2 & 34.4 & 13.6 & 10.8 & 93 \\
\hline 2013 & -0.4 & 12.7 & 15.4 & 17.2 & 19.2 & 15.4 & 98 & 12.4 & 17.9 & 109.2 & 47.8 & 17.1 & 10.3 & 67 \\
\hline
\end{tabular}

Note: Data for percentage of 30-year average is from Environment and Climate Change Canada's climate normals.

$\mathrm{m}^{-2}$ (Table 4). Since the fungicide was applied after the plant density was measured, it would not be expected to affect plant density. Panicle density responded to $\mathrm{N}$ rate but not to fungicide application or the interaction of fungicide $\times \mathrm{N}$ (Table 3 ). As the $\mathrm{N}$ rate increased, there was a linear increase in the panicle density from 408 to 462 panicles $\mathrm{m}^{-2}$. Increasing the panicle density increases the yield potential of the annual canarygrass. Similar trends were reported by May et al. (2012a) where $\mathrm{N}$ fertilizer rate did not impact plant density while causing a curvi-linear increase in panicle density from 465 to 507 panicles $\mathrm{m}^{-2}$ as the $\mathrm{N}$ rate increased from 20 to $70 \mathrm{~kg}$ $\mathrm{N} \cdot \mathrm{ha}^{-1}$. In this study the increase in panicle density started to increase at a slightly higher $\mathrm{N}$ rate, $30 \mathrm{~kg}$ $\mathrm{N}^{-} \mathrm{ha}^{-1}$ compared with $20 \mathrm{~kg} \mathrm{~N} \cdot \mathrm{ha}^{-1}$ in the previous study and in this study it panicle density continued to increase to $90 \mathrm{~kg} \mathrm{~N} \cdot \mathrm{ha}^{-1}$ while in the previous study panicle density peaked at $70 \mathrm{~kg} \mathrm{~N} \cdot \mathrm{ha}^{-1}$. This difference may be due to higher panicle density obtained by the previous study at a low $\mathrm{N}$ rate 465 panicles $\mathrm{m}^{-2}$ compared with the 407 panicles $\mathrm{m}^{-2}$ at a low $\mathrm{N}$ rate in this study so less $\mathrm{N}$ was required in the previous study to maximize panicle density. The increase in panicle or head density as the $\mathrm{N}$ rate increased has been observed in other small grains under similar environmental conditions including oat, wheat and barley (May et al. 2020a, 2020b; O’Donovan et al. 2015).

\section{Kernel density}

Kernel density was affected by $\mathrm{N}$ and fungicide application, but not by the $\mathrm{N} \times$ fungicide interaction (Table 3 ). The kernel density increased linearly as the $\mathrm{N}$ rate increased from 14240 kernels $\mathrm{m}^{-2}$ with $10 \mathrm{~kg} \mathrm{~N} \cdot \mathrm{m}^{-2}$ to 16648 kernels $\mathrm{m}^{-2}$ with $90 \mathrm{~kg} \mathrm{~N} \cdot \mathrm{m}^{-2}$ (Table 4). Fungicide increased kernel density from 15197 kernels $\mathrm{m}^{-2}$ to 16288 kernels $\mathrm{m}^{-2}$. As a yield component, this increase in the kernel density increased the yield potential of the annual canarygrass.

\section{Kernel weight}

Fungicide application and the $\mathrm{N}$ rate $\times$ fungicide application interaction had no effect on kernel weight (Table 3). There was a small linear decrease of $2.6 \%$ in kernel weight as $\mathrm{N}$ rate increased from $7.59 \mathrm{~g} \cdot 1000$ kernels $^{-1}$ at $10 \mathrm{~kg} \mathrm{~N} \cdot \mathrm{ha}^{-1}$ to $7.4 \mathrm{~g} \cdot 1000 \mathrm{kernels}^{-1}$ at $90 \mathrm{~kg} \mathrm{~N} \cdot \mathrm{ha}^{-1}$ (Tables 3 and 4). Kernel weight is the last yield component that can adjust to changes in environmental conditions during seed filling. This decrease in kernel weight as $\mathrm{N}$ rate increases indicates that the yield potential created by the increasing $\mathrm{N}$ rate became limited by other factors including environmental conditions. In contrast to this study, both May et al. (2012a) and Holt (1988) found that kernel weight was not affected by $\mathrm{N}$ rate. Holt (1988) had precipitation at or above the 30-year average during the years he conducted his study. May et al. (2012a) had precipitation that was closer to the current study with site years with precipitation at or above the 30-year average and other site years with a low level of precipitation during the growing season below the 30-year average. May et al. (2012a) did have a small numerical decrease in kernel weight as the $\mathrm{N}$ rate increased, but it was not statistically significant. It is important to note that the increase in yield potential as the $\mathrm{N}$ rate increased occurred in the yield components prior to kernel weight.

In this study the application of a fungicide affected kernel density but not kernel weight. Similar results in 
Table 3. Analysis of variance for the effect of fungicide and nitrogen on the development and grain yield of annual canarygrass over all sites and years.

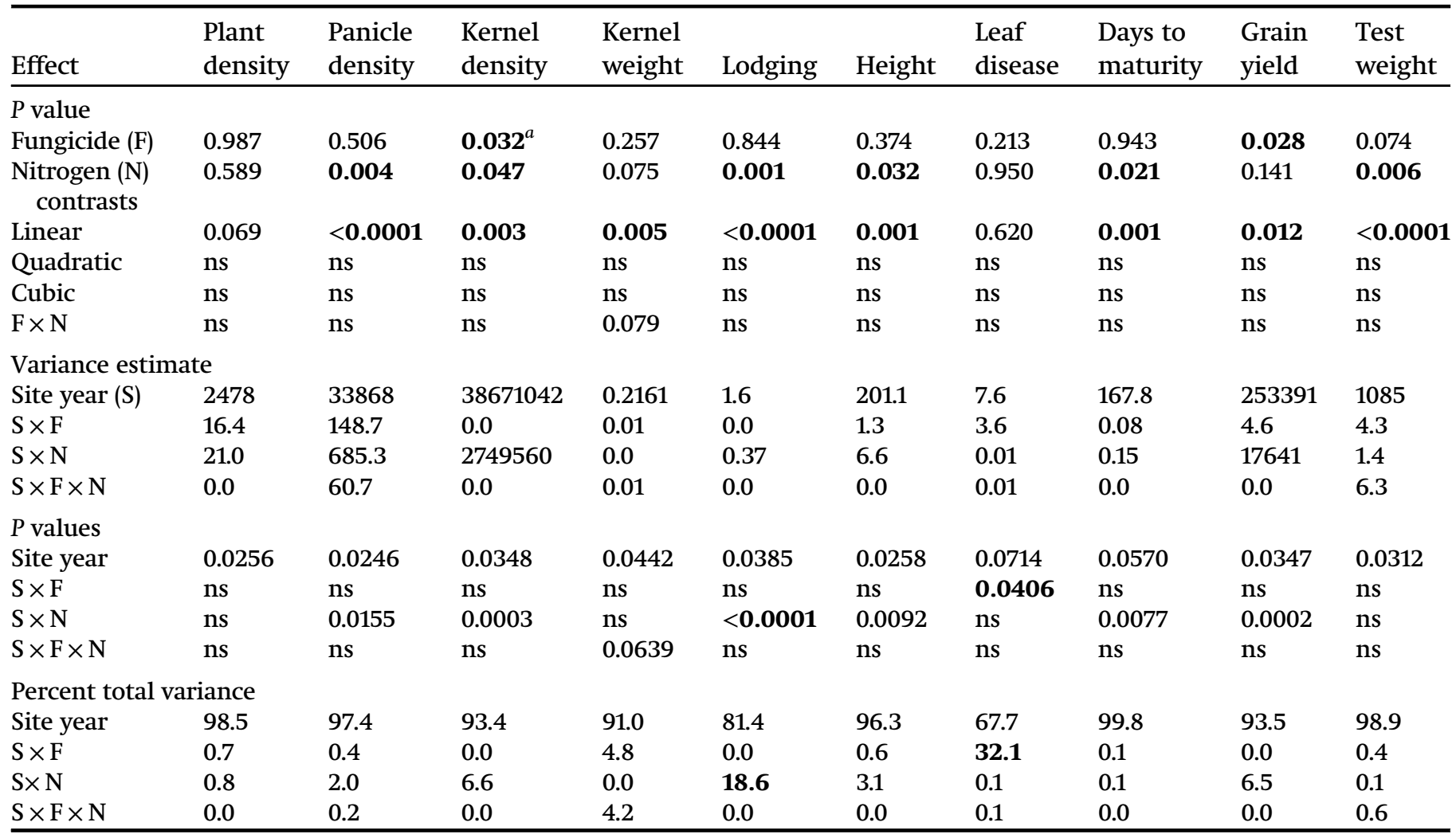

${ }^{a}$ All significant $P$ values for fixed effects are bolded and all significant $P$ values combined with a total variance above $10 \%$ for random effects are bolded. ns, not significant.

which kernel weight was the yield component affected by the fungicide application where found in oat (May et al. 2014a) and wheat (Kelley 2001); however, other studies found that both kernel density and kernel weight were increased by a fungicide application in other cereal crops including oat (Dietz et al. 2019), durum wheat [Triticum turgidum L. ssp. durum (Desf.) Husn] (May et al. 2014b), and barley (Safavi et al. 2012).

\section{Height and lodging}

Plant height was affected by $\mathrm{N}$ rate but not by an application of fungicide or the $\mathrm{N}$ rate $\times$ fungicide application interaction (Table 3). There was a linear increase in plant height from $91 \mathrm{~cm}$ to $95 \mathrm{~cm}$ as the $\mathrm{N}$ rate increased from 10 to $90 \mathrm{~kg} \cdot \mathrm{ha}^{-1}$ (Table 4). This small increase in plant height would not be expected to have a big impact on the development or grain yield of the annual canarygrass. May et al. (2012a) reached the same outcome, with $\mathrm{N}$ having a small effect on crop height, peaking at $101.7 \mathrm{~cm}$ with $70 \mathrm{~kg} \mathrm{~N} \cdot \mathrm{ha}^{-1}$. Holt (1988) reported a much bigger increase in plant height from $68 \mathrm{~cm}$ to $88 \mathrm{~cm}$ as the $\mathrm{N}$ rate increased from 0 to $100 \mathrm{~kg} \cdot \mathrm{ha}^{-1}$.

Lodging was not affected by a fungicide application. Holzapfel (2014) noted that on a field scale a fungicide application tended to reduced lodging improving the harvestability of the annual canarygrass crop. There was a small linear increase in lodging from 1.0 to 2.4 as the $\mathrm{N}$ rate increased from 10 to $90 \mathrm{~kg} \cdot \mathrm{ha}^{-1}$ (Table 4); however, this increase in lodging would not be expected to result in a yield decrease given that overall lodging especially at the higher $\mathrm{N}$ rates remained relatively minor. May et al. (2012a) also found that increasing the $\mathrm{N}$ rate resulted in a small increase in lodging, from 2.0 to 2.7 as the $\mathrm{N}$ rate increased from 20 to $100 \mathrm{~kg} \mathrm{~N} \cdot \mathrm{ha}^{-1}$ with little or any impact on grain yield. In this study, no significant interaction was found between fungicide and $\mathrm{N}$ for lodging. There was a significant site year $\times \mathrm{N}$ interaction for lodging with two of the nine sites-years having a moderate increase in lodging from 1 to 5 as the $\mathrm{N}$ rate increased, and four of the nine site years having no change in lodging as the $\mathrm{N}$ rate increased (data not shown). Therefore, in this study, increasing the $\mathrm{N}$ rate occasionally induce moderate lodging at specific site-years but at most site years the impact of $\mathrm{N}$ rates on lodging in annual canarygrass was low.

\section{Leaf disease}

Leaf disease severity was not affected by $\mathrm{N}$ rate, fungicide application or the $\mathrm{N}$ rate $\times$ fungicide application interaction and was fairly low throughout the trial (Tables 3 and 4). Relatively low levels of disease, 2.2 to 3.6 , occurred when averaged across the site years and 


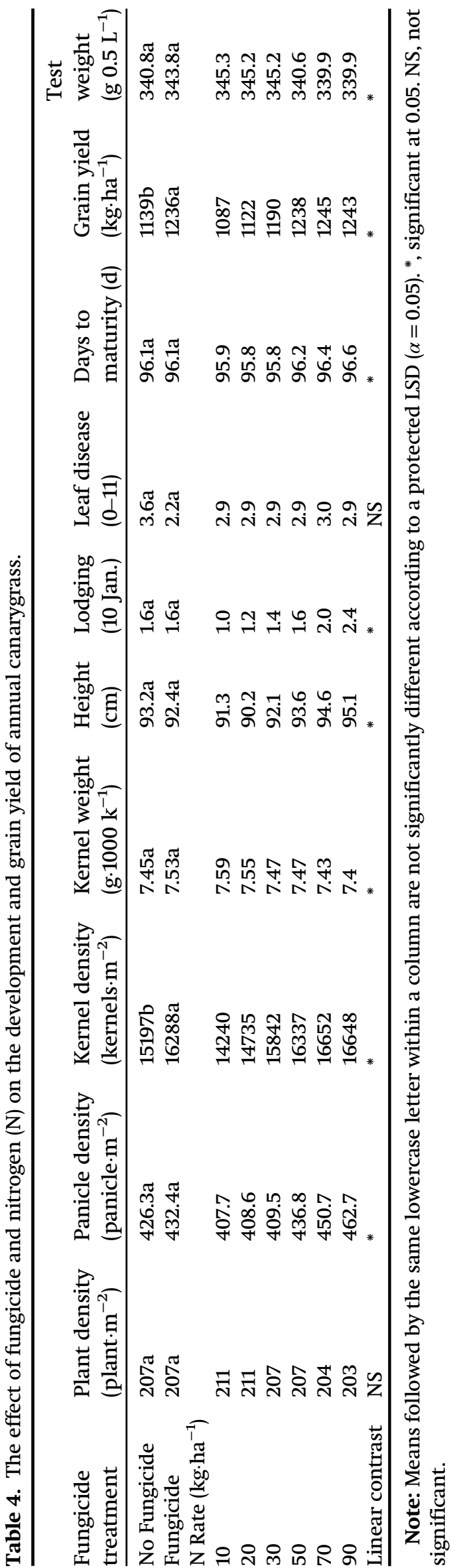

this may be why the overall fungicide was not significant. However, there was a significant site year $\times$ fungicide interaction with $32 \%$ of the variation due to the random effects for leaf disease, indicating that at some locations, fungicide application had an effect on disease severity. The no fungicide treatment had elevated levels of disease at 4 out of the 9 site years with the application of a fungicide reducing the disease rating by at least 1 on the rating scale. The low level of disease at the other 5 sites years resulted in the overall effect of fungicide on disease being non-significant. The elevated disease severity was recorded at two locations, Indian Head with McFadden ratings of 5.7 in 2012 and 8.2 in 2013 and Scott in with McFadden ratings of 7.8 in 2012 and 6.1 in 2013. These four site years do not have environmental conditions in common with growing season precipitation ranging from $141 \%$ to $73 \%$ of the $30 \mathrm{y}$ average, but what they do have in common are that large commercial fields of annual canarygrass are grown near Indian Head and Scott. This could allow inoculum of septoria leaf mottle to enter the plots at Indian Head and Scott earlier in the growing season and be detected by the disease ratings. A lack of consistent effect of fungicide on disease severity ratings combined with a consistent beneficial impact on grain yield may be due to measuring disease severity too early in the growing season. It should be noted that from personal observation that the severity of septoria leaf mottle does not increase until canopy closer occurs at anthesis. In addition annual canarygrass will initiate tiller later in the growing season if precipitation occurs during anthesis and early seed filling resulting in later cohorts of tillers. In the current study, the only yield component that was increased by a fungicide application was kernel density, which suggests that the panicles could set and support more seeds during reproductive development. Unfortunately, we did not take measurements to determine if this increase was on all panicles or mostly from a specific cohort of tillers (first, second or third) and if a late cohort was filling kernels in late Aug. and Sept. It is interesting to note that increasing the $\mathrm{N}$ rate had no impact on the disease severity observed in this study and this lack of response was consistent among site years.

\section{Days to maturity}

Days to maturity was affected by $\mathrm{N}$ rate but not by fungicide or the $\mathrm{N}$ rate $\times$ fungicide application interaction (Table 3). As the $\mathrm{N}$ rate increased annual canarygrass maturity was delayed from 95.9 to $96.6 \mathrm{~d}$ (Table 4). Overall the days to maturity observed in the current study was slightly shorter than the 100-110 d reported by Putnam et al. (1996); however, it is representative of the earlier maturity found in cultivars developed at the University of Saskatchewan breeding program, which typically reach maturity in $98 \mathrm{~d}$ (Government of Saskatchewan 2020b). In contrast to the current study, 
Fig. 1. Grain yield response of annual canarygrass to increasing nitrogen rates.

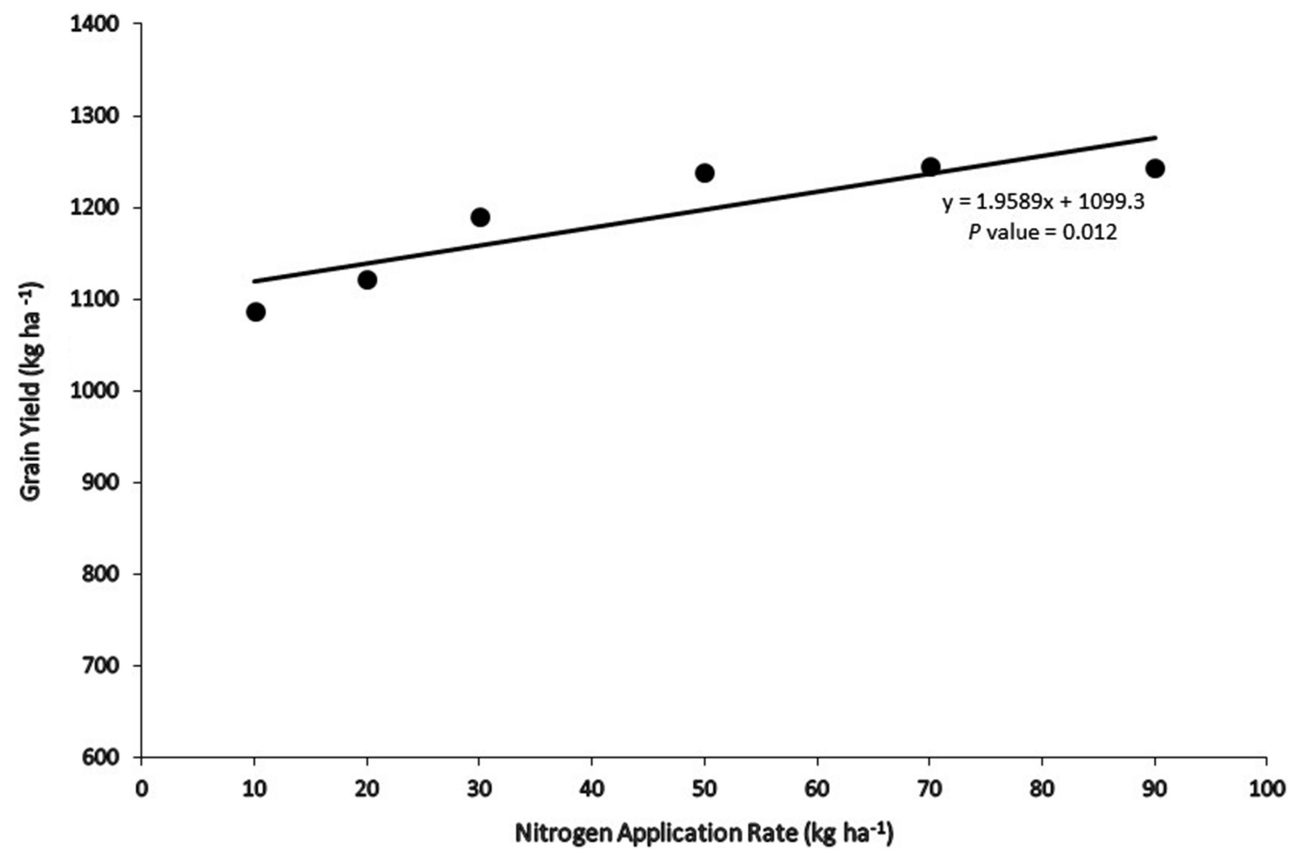

May et al. (2012a) reported that maturity did not respond to different rates of $\mathrm{N}$ fertilizer.

\section{Grain yield}

Fungicide application and $\mathrm{N}$ rate both affected grain yield while the interaction of $\mathrm{N}$ rate $\times$ fungicide application had no affect on grain yield (Table 3 ). The application of a fungicide increased grain yield by $8.5 \%$ from 1139 to $1236 \mathrm{~kg} \mathrm{ha}^{-1}$ (Table 4). The yield component that was responsible for increase in grain yield was kernel density. This indicates that the fungicide application either prevented seed abortion or increased initial seed set at anthesis. This suggests that at least a portion of this increase is due to improved control of septoria leaf mottle preventing a reduce supply of photoassimilates. The beneficial impact of a fungicide application on the grain yield of annual canarygrass was supported by Holzapfel (2014). In field scale trials near Indian Head, SK from 2004-2013, Holzapfel (2014) reported that, overall grain yield increased $23.2 \%$ following fungicide application versus the $8.5 \%$ increase observed in the current study.

As the $\mathrm{N}$ rate increased from 10 to $90 \mathrm{~kg} \mathrm{~N} \cdot \mathrm{ha}^{-1}$, there was a $14.4 \%$ linear increase in grain yield from $1087 \mathrm{~kg} \cdot \mathrm{ha}^{-1}$ to $1243 \mathrm{~kg} \cdot \mathrm{ha}^{-1}$ (Fig. 1). In this study, panicle density and kernel density were the yield components that responded to the applied $\mathrm{N}$ and contributed to the increase in grain yield. May et al. (2012a) found that panicle density was the yield component in annual canarygrass that responded to $\mathrm{N}$ fertilizer and contributed to grain yield. The lack of an interaction between $\mathrm{N}$ and fungicide application on grain yield indicates that growers can manage $\mathrm{N}$ fertilizer and disease control using foliar fungicides separately. This also indicates management of septoria using foliar fungicides in annual canarygrass does not impact the responsiveness of annual canarygrass to $\mathrm{N}$ fertilizer. In contrast to the current study, Holt (1988) reported a curvilinear increase of $79 \%$ in grain yield as the fertilizer $\mathrm{N}$ rate increased from 0 to $100 \mathrm{~kg} \mathrm{~N} \cdot \mathrm{ha}^{-1}$, whereby grain yield increased from 710 to $1270 \mathrm{~kg} \cdot \mathrm{ha}^{-1}$. May et al. (2012a) also reported a small curvilinear increase of $7 \%$ in grain yield by increasing $\mathrm{N}$ rate up to $78 \mathrm{~kg} \cdot \mathrm{ha}^{-1}$ with a maximum yield of $1216 \mathrm{~kg} \cdot \mathrm{ha}^{-1}$. Most of the increase occurred between the $20-40 \mathrm{~kg} \mathrm{~N} \cdot \mathrm{ha}^{-1}$ range, and using the coefficient of variation of each $\mathrm{N}$ rate across site years, they found that $\mathrm{N}$ fertilizer rates above $40 \mathrm{~kg} \mathrm{~N} \cdot \mathrm{ha}^{-1}$ had greater variation around the mean than the 20 and $40 \mathrm{~kg} \mathrm{~N} \cdot \mathrm{ha}^{-1}$ rates. The larger increase from applied $\mathrm{N}$ fertilizer observed by Holt (1988) may be due to the fact that, the research conducted by Holt was in a conventional tillage system verses a no-till cropping system in this study and in the May et al. (2012a) study. Long term no-till tends to have a higher level of residual $\mathrm{N}$ in the soil than a conventional cropping system (Jat et al. 2018; Lafond et al. 2011). In addition, the larger increase may be partially due to the fact that Holt (1988) started at a lower $\mathrm{N}$ rate, $0 \mathrm{~kg} \mathrm{~N} \cdot \mathrm{ha}^{-1}$, than this study with an initial $\mathrm{N}$ rate of $10 \mathrm{~kg} \mathrm{~N} \cdot \mathrm{ha}^{-1}$ and May et al. (2012a) with an initial $\mathrm{N}$ rate of $20 \mathrm{~kg} \mathrm{~N} \cdot \mathrm{ha}^{-1}$. Holt found that grain yield increased by $220 \mathrm{~kg} \cdot \mathrm{ha}^{-1}$ as the $\mathrm{N}$ rate increased from 0 to 25 and by $340 \mathrm{~kg} \cdot \mathrm{ha}^{-1}$ as the $\mathrm{N}$ rate increased from 25 to $100 \mathrm{~kg} \mathrm{~N} \cdot \mathrm{ha}^{-1}$. 
Table 5. The change in gross returns compared with $10 \mathrm{~kg} \mathrm{~N} \mathrm{ha}^{-1}$ as the nitrogen $(\mathrm{N})$ rate increased at three grain prices and three nitrogen prices over all sites and years.

\begin{tabular}{|c|c|c|c|c|c|}
\hline \multirow{2}{*}{\multicolumn{2}{|c|}{$\begin{array}{l}\text { Price of nitrogen } \\
\left(\$ \mathrm{~N} \mathrm{~kg}^{-1}\right)\end{array}$}} & \multirow{3}{*}{$\begin{array}{l}\mathrm{N} \text { rate } \\
\left(\mathrm{kg} \cdot \mathrm{ha}^{-1}\right)\end{array}$} & \multicolumn{3}{|c|}{$\begin{array}{l}\text { Price of annual canarygrass } \\
\left(\$ \cdot \mathrm{kg}^{-1}\right)\end{array}$} \\
\hline & & & 0.44 & 0.66 & 0.88 \\
\hline & & & \multicolumn{3}{|c|}{ Change in Gross return $\left(\$ \cdot h^{-1}\right)$} \\
\hline \multirow{6}{*}{\multicolumn{2}{|c|}{0.50}} & 10 & 0.00 & 0.00 & 0.00 \\
\hline & & 20 & 10.53 & 18.29 & 26.05 \\
\hline & & 30 & 35.34 & 58.00 & 80.67 \\
\hline & & 50 & 46.37 & 79.56 & 112.74 \\
\hline & & 70 & 39.51 & 74.26 & 109.00 \\
\hline & & 90 & 28.88 & 63.32 & 97.75 \\
\hline \multirow[t]{3}{*}{ Contrast } & Linear & & 0.2730 & 0.1132 & 0.0685 \\
\hline & Quadratic & & 0.1939 & 0.1939 & 0.1939 \\
\hline & Cubic & & 0.8730 & 0.8730 & 0.8730 \\
\hline \multirow[t]{6}{*}{0.75} & & 10 & 0.00 & 0.00 & 0.00 \\
\hline & & 20 & 8.03 & 15.79 & 23.55 \\
\hline & & 30 & 30.34 & 53.00 & 75.67 \\
\hline & & 50 & 36.37 & 69.56 & 102.74 \\
\hline & & 70 & 24.51 & 59.26 & 94.00 \\
\hline & & 90 & 8.88 & 43.32 & 77.75 \\
\hline \multirow[t]{3}{*}{ Contrast } & Linear & & 0.7304 & 0.2730 & 0.1434 \\
\hline & Quadratic & & 0.1939 & 0.1939 & 0.1939 \\
\hline & Cubic & & 0.8730 & 0.8730 & 0.8730 \\
\hline \multirow[t]{6}{*}{1.00} & & 10 & 0.00 & 0.00 & 0.00 \\
\hline & & 20 & 5.53 & 13.29 & 21.05 \\
\hline & & 30 & 25.34 & 48.00 & 70.67 \\
\hline & & 50 & 26.37 & 59.56 & 92.74 \\
\hline & & 70 & 9.51 & 44.26 & 79.00 \\
\hline & & 90 & -11.12 & 23.32 & 57.75 \\
\hline \multirow[t]{3}{*}{ Contrast } & Linear & & 0.6777 & 0.5506 & 0.2730 \\
\hline & Quadratic & & 0.1939 & 0.1939 & 0.1939 \\
\hline & Cubic & & 0.8730 & 0.8730 & 0.8730 \\
\hline
\end{tabular}

\section{Test weight}

Test weight was not affected by fungicide application but had a significant linear decrease with increasing $\mathrm{N}$ application (Tables 3 and 4). The test weight decreased from $345.3 \mathrm{~g} 0.5 \mathrm{~L} \cdot \mathrm{ha}^{-1}$ at $10 \mathrm{~kg} \mathrm{~N} \cdot \mathrm{ha}^{-1}$ to $339.9 \mathrm{~g} 0.5 \mathrm{~L}^{-1}$ at $90 \mathrm{~kg} \mathrm{~N} \cdot \mathrm{ha}^{-1}$. This is an important factor as test weight may indicate the physical quality of the grain, which helps to determine the price at which a farmer can sell the grain. Holt (1988) also found that the test weight

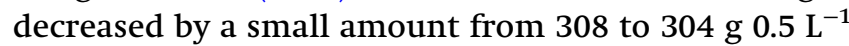
as the $\mathrm{N}$ rate increased from 25 to $100 \mathrm{~kg} \cdot \mathrm{ha}^{-1}$. It is interesting that in a genetically related cereal with a panicle type of inflorescence, oat, test weight declines as the fertilizer $\mathrm{N}$ rate is increased (Lafond et al. 2013; May et al. $2004 ; 2020 b$ ). Currently there is no clear explanation for this relationship.

\section{Change in gross return}

The change in gross return as the $\mathrm{N}$ rate increased was investigated using three $\mathrm{N}$ fertilizer prices and three grain prices. Under most of the nine combinations, the change in gross return as the $\mathrm{N}$ rate increased was not significant and the contrasts are included in Table 5 and Supplementary Table $S 1^{1}$. Since both the $\mathrm{N}$ rate and the contrasts were not significant no $\mathrm{N}$ rate can be recommended based on gross return; however, based on yield, $\mathrm{N}$ rates that provided the highest yields were at or above $50 \mathrm{~kg} \cdot \mathrm{ha}^{-1} \mathrm{~N}$. It is interesting to observe that as the price of the annual canarygrass increased to 0.88 $\$ \cdot \mathrm{kg}^{-1}$ and the cost of the $\mathrm{N}$ decreased to $0.50 \$ \cdot \mathrm{kg}^{-1}$, the change in gross return had its greatest range of 0 to $112 \$ \cdot h^{-1}$ and a linear contrast with a $P$ value of 0.0685 (Table 5); however, as the cost of nitrogen was increase

${ }^{1}$ Supplementary data are available with the article at https://doi.org/10.1139/cjps-2020-0221. 
Table 6. The change in the statistical power to detect significant differences as the number of replicates and site years change for the variables investigated in this study.

Estimated power (\%)

Number of site years

\begin{tabular}{|c|c|c|c|c|c|c|c|c|c|c|c|c|}
\hline $\begin{array}{l}\text { Replicates } \\
\text { per site }\end{array}$ & 1 & 2 & 3 & 4 & 5 & 6 & 1 & 2 & 3 & 4 & 5 & 6 \\
\hline & \multicolumn{6}{|c|}{ Fungicide } & \multicolumn{6}{|c|}{ Site year $\times$ Fungicide } \\
\hline 5 & 0.286 & 0.911 & 0.241 & 0.994 & 1.000 & 0.997 & - & 0.572 & 0.511 & 0.780 & 0.927 & 0.985 \\
\hline 6 & 0.334 & 0.953 & 0.280 & 0.998 & 1.000 & 0.999 & - & 0.652 & 0.594 & 0.858 & 0.967 & 0.996 \\
\hline 9 & 0.472 & 0.994 & 0.394 & 1.000 & 1.000 & 1.000 & - & 0.824 & 0.783 & 0.968 & 0.998 & 1.000 \\
\hline \multirow[t]{2}{*}{10} & 0.514 & 0.997 & 0.430 & 1.000 & 1.000 & 1.000 & - & 0.862 & 0.827 & 0.981 & 0.999 & 1.000 \\
\hline & \multicolumn{6}{|c|}{ Nitrogen } & \multicolumn{6}{|c|}{ Site year $\times$ Nitrogen } \\
\hline 4 & 0.931 & 0.309 & 1.000 & 1.000 & 0.766 & 1.000 & - & 0.922 & 0.465 & 1.000 & 1.000 & 1.000 \\
\hline 5 & 0.980 & 0.392 & 1.000 & 1.000 & 0.868 & 1.000 & - & 0.973 & 0.588 & 1.000 & 1.000 & 1.000 \\
\hline \multirow[t]{2}{*}{10} & 1.000 & 0.735 & 1.000 & 1.000 & 0.996 & 1.000 & - & 1.000 & 0.931 & 1.000 & 1.000 & 1.000 \\
\hline & \multicolumn{6}{|c|}{ Nitrogen $\times$ Fungicide } & \multicolumn{6}{|c|}{ Site year $\times$ Nitrogen $\times$ Fungicide } \\
\hline 4 & 0.217 & 0.198 & 0.180 & 0.383 & 0.350 & 0.344 & - & 0.090 & 0.095 & 0.562 & 0.603 & 0.554 \\
\hline 5 & 0.277 & 0.248 & 0.222 & 0.479 & 0.438 & 0.430 & - & 0.102 & 0.110 & 0.699 & 0.744 & 0.697 \\
\hline 6 & 0.339 & 0.298 & 0.265 & 0.569 & 0.522 & 0.512 & - & 0.115 & 0.125 & 0.804 & 0.846 & 0.807 \\
\hline 7 & 0.400 & 0.350 & 0.309 & 0.649 & 0.600 & 0.588 & - & 0.128 & 0.142 & 0.879 & 0.913 & 0.884 \\
\hline 8 & 0.460 & 0.401 & 0.353 & 0.718 & 0.669 & 0.657 & - & 0.141 & 0.159 & 0.929 & 0.953 & 0.934 \\
\hline 9 & 0.517 & 0.451 & 0.398 & 0.777 & 0.730 & 0.718 & - & 0.155 & 0.176 & 0.959 & 0.976 & 0.964 \\
\hline 10 & 0.571 & 0.499 & 0.441 & 0.826 & 0.782 & 0.770 & - & 0.169 & 0.195 & 0.978 & 0.988 & 0.981 \\
\hline
\end{tabular}

Note: Site $\times$ replication combinations that have a power greater than $80 \%$ have been bolded and should be able to detect differences between treatments.

to 0.75 and $1.0 \$ \cdot \mathrm{N} \mathrm{kg}^{-1}$ the range in gross return was numerically lower making it more difficult to detect differences as can be seen from the $P$ values of the linear contrasts 0.1132 at $0.75 \$ \cdot \mathrm{N} \mathrm{kg}^{-1}$ and 0.2730 at $1.0 \$ \cdot \mathrm{kg}^{-1}$. The variation in the data is too great to further refine the changes in gross return due to fertilizer and grain price.

Power of detection related to replication and location

When a study is conducted on a crop with limited research dollars, a better understanding of the number of replications and locations required to detect statistical differences is important when planning for future research. Statistical power is 1 - the type II error (not rejecting the null hypothesis when the null hypothesis is incorrect); therefore, as the statistical power increases the probability of a type II error decreases. Power analysis can be used to calculate the minimum sample size required to detect an effect of a given size. The approach used in this study and outlined by
Stroup (1999) has been used in a wide range of research including Wireworms, [Limonius californicus (Mannerheim) (Coleoptera: Elateridae)], a balsam fir forest, dairy nutrition and fish community composition (Bilotta et al. 2016; D’Orangeville et al. 2013; Kononoff and Hanford 2006; Loiewski and Wenninger 2019). When the data from this study was used to estimate the number of replications within a location and the number of locations required to detect significant treatment differences in grain yield the results varied between fungicide and $\mathrm{N}$ rate (Table 6). In this study we wanted to consistently obtain a power of 0.80 (Di Stefano 2003) or more before recommending a set number of replicates or locations for future studies. The analysis randomly selected individual site years to include and since the severity of disease varies among locations, the power to detect differences fluctuates as we add site years that differ in disease severity (Table 6). To consistently detect the overall effect of a fungicide application on grain yield over the region in which the study was 
conducted, 4 site years are recommended (Table 6). Increasing the replicates at each location did not have as great an impact as the number of site years. To differentiate the effects of a fungicide application on grain yield at different locations (site year $\times$ fungicide) the number of replicates at the four locations would have to be increased from 4 to 6 or the number of locations would have to be increased from 4 to 5 to obtain a power greater than 0.80 .

To consistently detect the impact of $\mathrm{N}$ fertilizer on grain yield over the region in which the study was conducted, the analysis indicates that 3 site years would be required. To differentiate between grain yield responses to $\mathrm{N}$ at different locations, 4 site years with 4 replicates or 3 site years with 8 replicates at each location would be required (Table 6). The need for fewer site years to detect the impact of $\mathrm{N}$ fertilizer than a fungicide application is probably due to the impact of $\mathrm{N}$ fertilizer varying on a range from small to large among the different site years while fungicides will have a large affect at the locations with elevated levels of disease and low to none at locations with low levels of disease. In this study we could not detect a interaction between $\mathrm{N}$ fertilizer and a fungicide using the entire data set (Table 3 ) so as expected an interaction was not detected using a subset of the entire data set (Table 6).

\section{Conclusion}

This study examines the relationship of $\mathrm{N}$ fertilizer and fungicides on crop development, septoria leaf mottle, grain yield and physical grain quality of annual canarygrass. Both $\mathrm{N}$ fertilizer and fungicide application increased grain yield. The response curve for $\mathrm{N}$ is slight with a rate of $50 \mathrm{~kg} \mathrm{~N} \cdot \mathrm{ha}^{-1}$ being sufficient to maximize yield and economic returns. In annual canarygrass it does not appear that the $\mathrm{N}$ rate recommended from this study would change if the cost of $\mathrm{N}$ was significantly increased. The results of this study indicate that growers cannot use leaf disease management with fungicides as a means to increase annual canarygrass's responsiveness to $\mathrm{N}$ fertilizer. The lower impact of disease on grain yield observed in this study compared with field scale research (Holzapfel 2014) indicates that more research is required into the effects of septoria leaf mottle on annual canarygrass and how to best measure the impact of disease on annual canarygrass. When measuring the impact of a fungicide on grain yield, a power analysis indicates that at least 5 site years will be required for future research. Finally, both $\mathrm{N}$ fertilizer and fungicide applications are important management practices in annual canarygrass. The lack of an interaction between $\mathrm{N}$ and fungicide application indicates that these two practices can be managed independently by annual canarygrass producers. The results from this study indicate that producers should use $50 \mathrm{~kg} \mathrm{~N} \cdot \mathrm{ha}^{-1}$ at seeding and apply a fungicide to control septoria leaf mottle after full emergence of the flag leaf.

\section{Acknowledgements}

The technical support of Rebecca Davies, Randy Shiplack, Kevin Willoughby, Kathy Ringdal, and Orla Willoughby at Indian Head, Lana Shaw at South East Research Farm, Mike Hall at the East Central Research Farm and Darwin Leach at the Melfort Research Station is recognized and appreciated. Statistical advice provided by Dr. Stevenson is appreciated. Funding was provided by Saskatchewan Ministry of Agriculture, the Canaryseed Development Commission of Saskatchewan and Agriculture and Agri-Food Canada.

\section{References}

Agriculture and Agri-Food Canada. 2020. Pulses and special crops supply and disposition. [Online]. Available from https://aimissimia.agr.gc.ca/rp/index-eng.cfm?action $=p R \& p d c t c=\& r=245$ [7 May 2020].

Berkenkamp, B., Jesperson, G., and Bissett, J.1989. Leaf mottle, a new disease of canarygrass caused by Septoria triseti Speg. Plant Dis. 73: 859. doi:10.1094/PD-73-0859E.

Berry, P.M., Sterling, M., Spink, J.H., Baker, C.J., SylvesterBradley, R., Mooney, S.J., et al. 2004. Understanding and Reducing Lodging in Cereals. Pages 217-271 in Advances in Agronomy. Academic Press.

Bilotta, G.S., Burnside, N.G., Gray, J.C., and Orr, H.G. 2016. The Effects of Run-of-River Hydroelectric Power Schemes on Fish Community Composition in Temperate Streams and Rivers. PLoS ONE, 11: e0154271. doi:10.1371/journal.pone.0154271. PMID:27191717.

Biswas, D.K., and Ma, B. 2016. Effect of nitrogen rate and fertilizer nitrogen source on physiology, yield, grain quality, and nitrogen use efficiency in corn. Can. J. Plant. Sci. 96: 392-403. doi:10.1139/cjps-2015-0186.

Canadian Grain Commission. 2016. Determining test weight | Chapter 1 - Official Grain Grading Guide. [Online]. Available from https://www.grainscanada.gc.ca/oggg-gocg/01/oggggocg-1-eng.htm [11 December 2016].

Canaryseed Development Commission of Saskatchewan. 2021. About canary seed. [Online]. Available from https:// www.canaryseed.ca/about.html [20 February 2021].

Dietz, J.I., Schierenbeck, M., and Simón, M.R. 2019. Impact of foliar diseases and its interaction with nitrogen fertilization and fungicides mixtures on green leaf area dynamics and yield in oat genotypes with different resistance. Crop. Prot. 121: 80-88. doi:10.1016/j.cropro.2019.03.017.

D’Orangeville, L., Houle, D., Côté, B., Duchesne, L., and Morin, H. 2013. Increased soil temperature and atmospheric $\mathrm{N}$ deposition have no effect on the $\mathrm{N}$ status and growth of a mature balsam fir forest. Biogeosciences, 10: 4627-4639. doi:10.5194/ bg-10-4627-2013.

Di Stefano, J. 2003. How much power is enough? Against the development of an arbitrary convention for statistical power calculations. Funct. Ecol. 17: 707-709. doi:10.1046/j.13652435.2003.00782.x.

Easson, D.L., White, E.M., and Pickles, S.J. 1993. The effects of weather, seed rate and cultivar on lodging and yield in winter wheat. J. Agric. Sci. 121: 145-156. doi:10.1017/S0021859 600077005

Environment and Climate Change Canada. 2020. Historical climate data. Government of Canada. [Online]. Available from https://climate.weather.gc.ca/index_e.html [30 July 2020].

Government of Saskatchewan. 2020a. AGR market trends. [Online]. Available from http://applications.saskatchewan.ca/ Default.aspx?DN=6dd2ea91-22e6-4095-9d2a-67ef8c822897\&l= English [26 Nov 2020]. 
Government of Saskatchewan. 2020b. Varieties of grain crops 2020. [Online]. Available from https://pubsaskdev.blob.core. windows.net/pubsask-prod/115091/Varieties\%252Bof\% 252BGrain\%252BCrops\%252B2020.pdf [30 July 2020].

Hamm, J.W., Radford, F.G. and Halstead, E.H. 1970. The simultaneous determination of nitrogen, phosphorus and potassium in sodium bicarbonate extracts of soils. Technicon International Congress, Advances in Automatic Analysis, Industrial Analysis Futura, Mont Kisco, New York. Vol. II: 65-69 pp.

Health Canada. 2016. Glabrous canary seed (Phalaris canariensis L.). Health Canada. [Online]. Available from https://www.canada.ca/ en/health-canada/services/food-nutrition/genetically-modifiedfoods-other-novel-foods/approved-products/glabrous-canaryseed-phalaris-canariensis.html [30 July 2020].

Holt, N.W. 1988. Effect of nitrogen fertilizer on the agronomic performance and seed quality of annual canarygrass. Can. J. Plant. Sci. 68: 41-45. doi:10.4141/cjps88-004.

Holzapfel, C.B. 2014. Field-scale evaluation of foliar applied fungicides for various crops. Indian Head Agricultural Research Foundation, Indian Head, Saskatchewan, Canada. 12 p. [Online]. Available https://iharf.ca/wp-content/uploads/2016/ 04/Field-Scale-Evaluation-of-Foliar-Applied-Fungicide-Optionsfor-Various-Crops.pdf [30 July 2020].

Jat, H.S., Datta, A., Sharma, P.C., Kumar, V., Yadav, A.K., Choudhary, M., et al. 2018. Assessing soil properties and nutrient availability under conservation agriculture practices in a reclaimed sodic soil in cereal-based systems of north-West India. Arch. Agron. Soil Sci. 64: 531-545. doi:10.1080/03650340.2017.1359415

Kaminski, D. 1994. Canaryseed and septoria leaf mottle. Crop Protection Newsletter. Government of Saskatchewan, Regina. $2 \mathrm{p}$

Kelley, K.W. 2001. Planting date and foliar fungicide effects on yield components and grain traits of winter wheat. Agron. J. 93: 380-389. doi:10.2134/agronj2001.932380x.

Kononoff, P.J., and Hanford, K.J. 2006. Technical Note: Estimating Statistical Power of Mixed Models Used in Dairy Nutrition Experiments. J. Dairy Sci. 89: 3968-3971. doi:10.3168/jds.S0022-0302(06)72439-0. PMID:16960072.

Lafond, G., Walley, F., May, W.E., and Holzapfel, C.B. 2011. Long term impact of no-till on soil properties and crop productivity on the Canadian prairies. Soil Tillage Res. 117: 110-123. doi:10.1016/j.still.2011.09.006.

Lafond, G.P., May, W.E., and Holzapfel, C.B. 2013. Row spacing and Nitrogen Fertilizer Effects on No-till Oat Production. Agron. J. 105: 1-10.

Lojewski, J.A., and Wenninger, E.J. 2019. Comparison of Two Different Statistical Methods for Assessing Insecticide Efficacy in Small Plot Trials Targeting Wireworms, Limonius californicus (Mannerheim) (Coleoptera: Elateridae), in Potato. Am. J. Potato Res. 96: 578-587. doi:10.1007/s12230-01909748-1.

Littell, R.C., Milliken, G.A., Stroup, W.W., and Wolfinger, R.D. 2006. SAS system for mixed models. 2nd ed. SAS Institute, Cary, NC.

May, W.E., Mohr, R.M., Lafond, G.P., Johnston, A.M., and Stevenson, F.C. 2004. Effect of nitrogen, seeding date and cultivar on oat quality and yield in eastern Canadian prairies. Can. J. Plant. Sci. 84: 1025-1036. doi:10.4141/P04-044.

May, W.E., Lafond, G.P., Gan, Y., Hucl, P., Holzapfel, C.B., Johnston, A., and Stevenson, C. 2012a. Yield variability in Phalaris Canariensis $\mathrm{L}$. due to seeding date, seeding rate and nitrogen fertilizer. Can. J. Plant. Sci. 92: 651-669. doi:10.4141/ cjps2011-126.

May, W.E., Malhi, S.S., Holzapfel, C.B., Nybo, B.X., Schoneau, J.J., and Lafond, G.P. 2012b. The effects of chloride and potassium nutrition on seed yield of annual canarygrass. Agron. J. 104: 1023-1031. doi:10.2134/agronj2011.0414.

May, W.E., Ames, N., Irvine, R.B., Kutcher, H.R., Lafond, G.P., and Shirtliffe, S.J. 2014a. Are fungicide applications to control crown rust of oat beneficial? Can. J. Plant. Sci. 94: 911-922. doi:10.4141/cjps2013-333.

May, W.E., Fernandez, M.R., Selles, F., and Lafond, G.P. 2014b. Agronomic practices to reduce leaf spotting and Fusarium kernel infections in durum wheat on the Canadian prairies. Can. J. Plant. Sci. 94: 141-152. doi:10.4141/cjps2012-304.

May, W.E., Aldous, L., and Lafond, G.P. 2020a. Feasibility of a wider row spacing and recommended nitrogen in no-till wheat. Agron. J. 112: 4076-4091. doi:10.1002/agj2.20316.

May, W.E., Brandt, S., and Hutt-Taylor, K. 2020b. The response of oat grain yield and quality to nitrogen fertilizer and fungicides. Agron. J. 112: 1021-1034. doi:10.1002/agj2.20081.

McFadden, W. 1991. Etiology and epidemiology of leaf spotting diseases in winter wheat in Saskatchewan. Ph.D. thesis, University of Saskatchewan, Saskatoon. $151 \mathrm{pp}$.

Meyer-Aurich, A., Karatay, Y.N., Nausediene, A., and Kirschke, D. 2020. Effectivity and Cost Efficiency of a Tax on Nitrogen Fertilizer to Reduce GHG Emissions from Agriculture. Atmosphere, 11: 607. doi:10.3390/atmos11060607.

Nakajima, T., Yoshida, M., and Tomimura, K. 2008. Effect of lodging on the level of mycotoxins in wheat, barley, and rice infected with the Fusarium graminearum species complex. J. Gen. Plant Pathol. 74: 289-295. doi:10.1007/s10327-008-0103-7

O’Donovan, J.T., Anbessa, Y., Grant, C.A., Macleod, A.L., Edney, M.J., Izydorczyk, M.S., et al. 2015. Relative responses of new malting barley cultivars to increasing nitrogen rates in western Canada. Can. J. Plant. Sci. 95: 831-839. doi:10.4141/ cjps-2014-415

Putnam, D.H., Miller, P.R., and Hucl, P. 1996. Potential for production and utilization of annual canarygrass. Cereal Foods World, 41: 74-83.

Safavi, S.A., Babai-Ahari, A., Afshari, F., and Arzanlou, M. 2012. Effect of yellow rust on yield components of barley cultivars with race-specific and slow rusting resistance to yellow rust. Arch. Phytopathol. Plant Prot. 45: 1488-1498. doi:10.1080/ 03235408.2012 .677493$.

SAS Institute. 2013. SAS/STAT ${ }^{\circledR} 13.1$ User’s Guide. SAS Institute Inc., Cary, NC.

Stroup, W.W. 1999. Mixed model procedures to assess power, precision, and sample size in the design of experiments. Proc. of the Biopharmaceutical Section of the American Statistical Association, 1999, Baltimore, MD.

Tridge. 2020. Canary seed. [Online]. Available from https:// www.tridge.com/intelligences/canary-seed/production [11 July 2020]. 